\title{
0 Estado nacional e a instabilidade da propriedade escrava: a Lei de 1831 e a matrícula dos escravos de $1872^{1}$
}

The Brazilian State and the Instability of Slave Property: the 1831 Law and the Slave Registry of 1872

\section{Beatriz Gallotti Mamigonian \\ Professora no Departamento de História da Universidade Federal de Santa Catarina (CFH/UFSC- Florianópolis/Brasil) e doutora em História pela University of Waterloo (Waterloo/Canadá). \\ e-mail: beatriz.mamigonian@ cfh.ufsc.br}

\section{Resumo}

0 artigo demonstra que a matrícula dos escravos determinada pela lei do Ventre Livre (28/09/1871) teve a intenção de legalizar a propriedade sobre os africanos trazidos por contrabando, que pela lei de 7/11/1831 deveriam ser considerados livres. Apesar da propriedade sobre os africanos importados desde 1831 ser aceita em transações comerciais e ser garantida pelo governo, o receio demonstrado pelos senhores de escravos em petições e as justificativas apresentadas no debate do projeto da lei de 1871 indicam que ela era considerada instável. As principais fontes utilizadas foram debates parlamentares, legislação, atas do Conselho de Estado e obras políticas.

\begin{abstract}
The article demonstrates that the slave registry instituted by the Free Womb Law $($ September 28, 1871) was intended to legalize the property over the Africans who were brought through the illegal slave trade and who should be considered free according to the abolition law of November 7, 1831. Despite the fact that successive governments guaranteed slave property and that it served as legal in commercial transactions, the fears demonstrated by slaveowners in petitions and the arguments presented in the debate of the Free Womb bill in 1871 indicate that property over the Africans imported since 1831 was considered unstable. The work is based on Brazilian parliamentary debates, legislation, State Council proceedings and decisions and political literature.
\end{abstract}

Palavras-chave

tráfico ilegal de escravos, lei de 1831, abolicionismo britânico, africanos livres, lei de 1871, matrícula dos escravos

\section{Keywords}

illegal slave trade, 1831 abolition law, British abolitionism, liberated Africans, 1871 law, slave registry financiado pelo CNPq e apoiado com bolsa de produtividade em pesquisa. 
"Parecer de 22 de junho de 1863". O Conselho de Estado e a Política Externa do Império: Consultas da Seção dos Negócios Estrangeiros: 1863-1867. Brasilia: Funag, 2007. p.39.
Em abril de 1863, a Assembleia da província de São Pedro do Rio Grande do Sul encaminhou uma representação ao Imperador denunciando o que os representantes acreditavam ser uma violação do tratado assinado pelo Império com o Uruguai em 1851 a respeito da devolução de escravos de senhores brasileiros que fugissem para o território da nação vizinha. Os representantes da província sulina relatavam que as autoridades uruguaias vinham exigindo dos senhores de escravos uma prova de propriedade antes de proceder à extradição dos indivíduos reclamados e que só aceitavam certidão de batismo que fosse certificada pela autoridade consular do lugar onde o indivíduo tivesse nascido. Para os brasileiros, essa exigência era uma quebra do tratado de 1851. Para justificar a dificuldade em obter os documentos exigidos e desqualificar as demandas das autoridades uruguaias, os deputados provinciais admitiram que "a maior parte dos escravos nesta província são comprados, quer sejam filhos d'África, quer das províncias irmãs, quer ainda desta província e (...) nossa lei não exige que a transferência do escravo seja acompanhada da certidão de batismo".2 Levada a exame pela seção de negócios estrangeiros do Conselho de Estado, a representação expôs um problema que transbordava o direito civil e ganhava exposição na arena das relações internacionais: o da falta de registros legais dos escravos, particularmente dos africanos, consequência do tráfico ilegal. Uma questão como essa, de identificação de sujeitos protegidos pela lei, ou pela nacionalidade, era própria dos processos de formação do Estado, tanto no Uruguai quanto no Brasil, mas expunha um problema candente num momento delicado para o Brasil.

0 relator, Visconde do Uruguai, e os outros dois conselheiros encarregados do parecer, o Visconde de Maranguape e Eusébio de Queirós, se eximiram de resolver o impasse, demonstrando apenas que a exigência uruguaia era cabivel e não configurava uma quebra do acordo bilateral. Segundo eles, as autoridades uruguaias tinham pleno direito de julgar "não se é legítima e admissível a propriedade do homem, mas se o reclamado é com efeito escravo, se é a pessoa própria que o documento faz propriedade". Em seguida, discorreram sobre o problema dos registros dos escravos:

0 escravo não tem estado civil. Quase que sempre tem um nome, o de batismo. Não tem apelidos de família. (...) No assento de batismo, quando o fazem, apenas se the menciona um nome e o do senhor e, quando muito, o de sua mãe. Nos títulos de venda apenas se the menciona o nome de batismo, o do vendedor e comprador e se declara, genericamente, que é da nação (se é africano) sem declarar qual seja, ou crioulo, se é nascido no Brasil, seja onde for. Portanto, as certidões de batismo e os títulos de venda laboram em um vago extraordinário. Demais, os escravos africanos não têm certidão de idade. Da maior parte, principalmente dos que foram introduzidos depois da extinção do tráfico, não há títulos de venda. ${ }^{3}$

Os conselheiros reconheciam que os documentos aceitos no Brasil operavam "em um vago extraordinário" e estavam baseados quase exclusivamente em dados que logravam provar a propriedade de um escravo, mas não cumpriam as funções de identificar com precisão um indivíduo e de diferenciá-lo de outros com o mesmo nome.

Atentos à contradição entre a prática brasileira de relegar a identificação individual a critérios definidos no âmbito privado e as tendências dos direitos civil e internacional de regulamentar essas matérias e de estabelecer registros públicos dos indivíduos, os conselheiros se limitaram 
a apontar que o impasse não derivava de quebra do tratado por parte dos uruguaios, mas da deficiência dos registros brasileiros:

Essa confusão foi, de indústria, mantida e argumentada, durante o largo tempo em que se fez o tráfico. Era indispensável não consagrar, em documentos, provas da importação ilícita. É este o caso em que se acha esse assunto. Daí que, não da violação do tratado, derivam as dificuldades, cuja remoção pede a assembleia de $\mathrm{S}$. Pedro do Sul. Essas dificuldades sana-as entre nós o geral e recíproco interesse dos senhores. Avultam, porém, quando aproveitadas por nações vizinhas. Assim, ou a República Oriental há de abster-se de examinar e discutir todo e qualquer pedido de devolução de escravos e limitar-se a entregar o individuo que the for apontado embora desconfie da identidade da pessoa, ou de que nasceu em seu território, ou de que ficou livre, entrando nele com consentimento do senhor - ou o tratado tem de 4 Ibidem, p.42. ser não violado, em princípio, mas inutilizado, na maior parte dos casos. ${ }^{4}$

Resguardados pelo sigilo das reuniões do Conselho, o Visconde do Uruguai, o Visconde de Maranguape e Eusébio de Queirós indicaram o que Ihes parecia ser a causa do problema: a "confusão", isto é, a falta de registros claros, que seria resultado da fase do tráfico ilegal, quando havia preocupação em se evitar o registro do contrabando de africanos. Não era uma questão de omissão, entretanto. Os conselheiros escolheram as palavras para qualificar a "confusão": ela foi "mantida e argumentada", disseram, "de indústria", isto é, de propósito. Além disso, com a construção na voz passiva, os conselheiros evitaram identificar atores e atribuir responsabilidade pela "confusão". Indicaram apenas que a situação não era fruto do acaso nem de omissão, e encontrava respaldo num agente coletivo.

Naquele momento, o impasse decorria do fato de que a prática consolidada historicamente resultava em um problema diplomático, pois as "dificuldades" no Brasil eram sanadas pelo "geral e recíproco interesse dos senhores", mas avultavam "quando aproveitadas por nações vizinhas". Essa observação também é muito interessante. Nela, os conselheiros reconheceram que a ameaça à ilegalidade da propriedade adquirida por contrabando vinha de fora pois, internamente, a conivência geral impedia que as "dificuldades" aflorassem. Também sugeriram que naquele momento o Uruguai se aproveitava delas, o que remetia ao fato de que o partido blanco uruguaio, oposto aos interesses dos estancieiros brasileiros, usava a questão para prejudicá-los. Mas, para além de um quesito de discórdia a alimentar a "Questão Platina", o problema da ilegalidade da escravidão se revelava um ponto fraco para o Brasil. A pressão externa não vinha só do país vizinho. Os conselheiros omitiram, convenientemente, a pressão que 0 ministro britânico William Christie vinha exercendo sobre o governo imperial desde 1860, o que havia, junto com outras questões menores, motivado a quebra de relações diplomáticas entre as duas coroas no início daquele mesmo ano. Tratava-se, justamente, da lentidão na emancipação definitiva dos africanos livres (pelo decreto de 1853) e da falta de um registro geral deles que permitisse identificar quem já estava emancipado e quem ainda cumpria serviços. Além disso, Christie insistia em cobrar providências do governo a respeito dos africanos trazidos por contrabando, estimados em Macmillan: London, 1865; GRAHAM, Richard. Os fundamentos da ruptura de relações diplomáticas entre o Brasil e a Grã-Bretanha em 1863: a "Questão Christie". Revista de História, vol.24, n.49, p.117-137 e p.379-400, jan./mar. 1962. que tornava a questão diplomática com a Inglaterra mais delicada era 0 potencial de agravar essas questões por dar-lhes publicidade.

Os impasses identificados no parecer da Seção de Estrangeiros em 1863 e nas reclamações de Christie tornaram mais urgente a discussão do 
6

Como indicarei mais adiante, o problema da instabilidade da propriedade escrava e da precariedade da liberdade também se aplicava aos casos nas fronteiras que suscitaram inúmeras disputas diplomáticas e ações judiciais nas décadas de 1850 e 1860; caberia avaliar como influenciaram o debate político imperial na segunda metade da década de 1860 , mas não pude fazê-lo aqui.

7

ALENCASTRO, Luiz Felipe. La traite négrière et I'unité nationale brésilienne. Revue Française d'Histoire d'Outre-Mer, tomo 66, n.244-245, p.395-417, 1979.
8

SÁBATO, Hilda (org.). Ciudadanía política y formación de las naciones: perspectivas históricas de América Latina. Cidade do México: Fideicomiso Historia de las Americas/Fondo de Cultura Economica/Colegio de Mexico, 1999; SCOT, James C. Seeing like a state: how certain schemes to improve the human condition have failed. New Haven: Yale University Press, 1998. p.25-73; LOVEMAN, Mara. Blinded like a state: the revolt against civil registration in nineteenth-century Brazil. Comparative Studies in Society and History, vol.49, n.1, p.5-39, 2007.

9

MATTOS, Hebe Maria. Escravidão e cidadania no Brasil monárquico. Rio de Janeiro: Zahar, 2000; GRINBERG, Keila. Alforria, direito e direitos no Brasil e nos Estados Unidos. Estudos Históricos, n.27, p.63-83, 2001; Idem. O fiador dos brasileiros: cidadania, escravidão e direito civil no tempo de Antônio Pereira Rebouças. Rio de Janeiro: Civilização Brasileira, 2002. "problema do elemento servil". A solução para o problema dos registros dos escravos foi dada pela chamada Lei do Ventre Livre, de 28 de setembro de 1871, que, além de libertar o ventre, regular a alforria, estabelecer o fundo de emancipação e libertar os últimos escravos da nação, também impôs a primeira matrícula geral dos escravos residentes no Brasil, executada em 1872. Era um levantamento nominal de todos os escravos existentes no Império. 0 registro serviria, dali em diante, como identificação dos escravos e prova de propriedade para os senhores, e seria requerido em todas as transações civis e comerciais.

Neste artigo, proponho reconstituir o debate político acerca dos registros da propriedade escrava, especialmente dos africanos importados depois da proibição do tráfico, até a promulgação da lei de $1871 .{ }^{6}$ Apesar de a propriedade sobre os africanos parecer segura e incontestada aos historiadores que trabalham com dados relativos à fortuna dos senhores de escravos - hipotecas, compras de escravos, partilhas de bens -, várias passagens do debate político desde a década de 1830 indicam que ela estava em questão. Acompanhar o debate público do "encaminhamento da questão servil" na década de 1860 sob o prisma do conflito das interpretações da lei de 1831 permite ver com novos olhos a lei de 1871. Ao identificar motivos até agora inexplorados para a implantação de uma matrícula geral dos escravos, 0 artigo aborda por um novo ângulo a história da conivência com o tráfico ilegal sobre a qual se fundou o Estado nacional brasileiro no século XIX.?

\section{A construção do Estado nacional, a abolição do tráfico e a manutenção da escravidão}

A distinção jurídica entre livres e escravos era elemento central da estrutura de uma sociedade escravista, provavelmente o mais importante. Essa distinção se tornou mais difícil e complexa com o avanço do abolicionismo atlântico no século XIX, quando as fronteiras entre a escravidão e a liberdade se multiplicaram e, em alguns sentidos, se tornaram mais permeáveis. A abolição do tráfico de escravos impôs o fim da incorporação de africanos novos e declarou livres os recém-chegados. A expansão das zonas de "solo livre" graças a decisões legais e à emancipação dos escravos em alguns territórios criou zonas de atração para escravos fugitivos e gerou conflitos diplomáticos a respeito dos limites geográficos que separavam a escravidão da liberdade.

0 século foi também marcado pela formação dos Estados nacionais nos territórios independentes das Américas. Como na construção do Estado moderno na Europa, o processo envolveu a centralização do poder, a codificação das normas legais, a demarcação das fronteiras nacionais e a definição dos direitos à cidadania, além do estabelecimento de padrões unificados para medidas, para nomes e para as línguas nacionais. ${ }^{8}$ Enquanto os construtores do Estado lidavam com populações heterogêneas tanto na Europa quanto nas Américas, somente nestas tiveram o desafio de acomodar a cidadania liberal com a manutenção da escravidão. Nos casos dos Estados Unidos e do Brasil em particular, definir claramente os limites entre a escravidão e a liberdade e regular a passagem para a liberdade foram tarefas fundamentais na construção da nova ordem legal. Tratavase, entre outras coisas, de definir quem fazia parte e quem estava excluído do corpo de cidadãos. ${ }^{9}$

No Brasil, a tarefa dos construtores do Estado nacional se complicou pelas circunstâncias da proibição do tráfico de escravos e pela continuação 
10

CONRAD, Robert E. Neither slave nor free: the Emancipados of Brazil, 1818-1868. Hispanic American Historical Review, n.53, p.50-70, 1973; MAMIGONIAN, Beatriz G. To be a liberated African in Brazil: labour and citizenship in the nineteenth century. Tese (Doutorado em História). University of Waterloo, 2002; ELTIS, David. Economic Growth and the Ending of the Transatlantic Slave Trade. Oxford: Oxford University Press, 1987. p.243244; MAMIGONIAN, Beatriz G. 0 direito de ser africano livre: os escravos e as interpretações da lei de 1831. In: LARA, Silvia H.; MENDONÇA, Joseli N. (orgs.). Direitos e justiças no Brasil: ensaios de História Social. Campinas: Ed. da Unicamp, 2006. p.129-160.

GRINBERG, Keila. Escravidão, direito e alforria no Brasil oitocentista: reflexões sobre a lei de 1831 e o "princípio da liberdade" na fronteira sul do Império brasileiro. In: CARVALHO, José Murilo de (org.). Nação e cidadania no Império. Rio de Janeiro: Civilização Brasileira, 2007. p.267-287.

12

BORUCKI, Alex; CHAGAS, Karla; STALLA, Natalia. Esclavitud y trabajo: un estudio sobre los afrodescendientes en la frontera uruguaya, 1835-1855. 2a ed. Montevideo: Mastergraf, 2009 p.114-158; CARATTI, Jônatas Marques. O Solo da Liberdade: As trajetórias da preta Faustina e do pardo Anacleto pela fronteira rio-grandense em tempos do processo abolicionista uruquaio (1842-1862). Dissertação (Mestrado em História). Universidade do Vale do Rio dos Sinos, 2010; LIMA, Rafael Peter de. 'A Nefanda Pirataria de Carne Humana': Escravizações ilegais e relações políticas na fronteira do Brasil Meridional (1851-1868). Dissertação (Mestrado em História). Universidade Federal do Rio Grande do Sul, 2010; CARATII, Jônatas Marques. Os extraditados: a ação do consulado uruguaio na libertação dos negros orientais escravizados ilegalmente na província de São Pedro do Rio Grande do Sul (décadas de 1850 e 1860). Mouseion, vol.2, n.3, p.91-107, 2008; GRINBERG, Keila. Escravidão, direito e alforria no Brasil oitocentista...Op. Cit., p.276-278.

13

BENTON, Lauren. "The Laws of This Country": Foreigners and the Legal Construction of Sovereignty in Uruguay, 1830-1875. Law and History Review, vol19, n.3, p.479-511, 2001. da importação de africanos mesmo após a entrada em vigência dos tratados e da lei de 7 de novembro de 1831. Mesmo após convenções bilaterais terem criado a categoria especial de "africanos livres" para enquadrar aqueles que fossem emancipados dos navios condenados por tráfico ilegal, categoria que implicava tutela do Estado por 14 anos e trabalho obrigatório, o tráfico ilegal ainda trouxe para o Brasil em duas décadas aproximadamente 760 mil africanos, que, de acordo com o primeiro artigo da lei de 1831, deveriam ser considerados livres, mas foram mantidos como escravos. ${ }^{10}$

No século XIX, por força tanto da construção do Estado nacional quanto do avanço do abolicionismo atlântico, aumentou gradualmente a intervenção do Estado na relação entre senhores e escravos. No campo do Direito, esse avanço se deu em paralelo à valorização do direito positivo e aos esforços de codificação. Já considerada contrária ao direito natural, a escravidão no século XIX se justificava somente com base no direito positivo: escravos eram um bem e como tal podiam ser comprados, vendidos, herdados ou penhorados. Eram propriedade, e o direito à propriedade, um dos cernes do liberalismo, era garantido pela Constituição de 1824.

Foi significativo que a manutenção da escravidão no Brasil e a garantia dos direitos dos proprietários brasileiros tenham exigido do Estado, em particular da diplomacia brasileira, como demonstrou Keila Grinberg, um esforço de regulamentação do "solo escravo"." Na fronteira sul do Brasil, a questão era particularmente delicada. A abolição da escravidão no Uruguai, em 1842, multiplicou os impasses legais a respeito das pessoas que transpunham a fronteira, voluntariamente ou não. Escravos que o faziam a serviço de senhores brasileiros teriam direito à liberdade; ex-escravos no Uruguai tinham de ser submetidos a contratos de peonagem; negros livres uruguaios eram raptados e escravizados no Brasil. A escravização de pessoas nascidas no Uruguai por senhores brasileiros no Rio Grande do Sul vinha sendo objeto de intensa correspondência diplomática entre os representantes uruguaios e as autoridades brasileiras e de inúmeras ações judiciais desde a década de 1850. Tratava-se de reverter a escravização de pessoas "arrebatadas" no Estado Oriental ou que pertenciam a proprietários de terras de fronteira e, fossem nascidas no Uruguai ou no Brasil, transitavam nos dois territórios e eram tidas como escravas. Nisso, o governo Imperial contrariava os interesses dos proprietários da região de fronteira e, significativamente, reconhecia a validade da lei de $1831 .{ }^{12}$ Do lado uruguaio, como demonstrou Lauren Benton, as demandas e os conflitos legais gerados pelos residentes estrangeiros (entre eles expressivo contingente de brasileiros) foram fundamentais para a construção da soberania do Estado uruguaio no século XIX, incentivando a codificação e o fortalecimento das instituições e autoridades nacionais. ${ }^{13}$ Pode-se ver, por esse ângulo, que a demanda uruguaia de registros dos escravos reclamados por brasileiros provavelmente fazia parte do processo de fortalecimento interno de suas instituições e legislação.

Que essas questões ficassem adscritas às negociações diplomáticas ou ao debate político nos gabinetes era a expectativa dos senhores de escravos e dos governantes brasileiros. No entanto, em 1863, vivia-se o segundo momento em que a política diplomática britânica buscou trazer a questão dos africanos a público. A questão era explosiva: ninguém conseguia calcular a proporção dos escravos que seriam ilegais e teriam direito à 
GRAHAM, Richard. Os fundamentos da ruptura... Op. Cit., p.117.
15

MAMIGONIAN, Beatriz G. In the name of freedom: slave trade abolition, the law and the Brazilian branch of the African emigration scheme (Brazil-British West Indies, 1830s-1850s). Slavery and Abolition, vol.30, n.1, p.41-66, mar. 2009.

16

Barão de Penedo para Ministro das Relações Exteriores, Londres, 08/09/1860. Lata 916, vol.5. Estrangeiros Confidenciais. Coleção Barão de Penedo. Arquivo Histórico do Itamaraty. emancipação imediata, nem tinha como garantir a ordem caso se aplicasse a lei. Os senhores e o governo temiam que a publicidade da ilegalidade do cativeiro de boa parte dos africanos dada pela Questão Christie gerasse instabilidade na autoridade sobre todos os escravos.

Quando as demandas exageradas do ministro britânico William D. Christie relativas à indenização pelo naufrágio do Prince of Wales e ao tratamento dos oficiais do Forte culminaram no bloqueio do porto do Rio de Janeiro e forçaram o governo brasileiro a pedir o rompimento das relações diplomáticas entre os dois países no início de janeiro de 1863, as ações do ministro britânico ganharam publicidade nacional e excitaram os ânimos nacionalistas. Subscrições populares arrecadaram fundos para o caso de uma guerra; o Imperador falou ao povo e foi aclamado com fervor; e Christie partiu temendo ser atacado na rua. ${ }^{14}$ Embora o governo brasileiro nunca tenha admitido nos relatórios ou correspondência oficial publicada que a "questão inglesa", como era chamada, tenha se agravado por causa da insistente defesa de Christie pela liberação dos africanos livres sob tutela e pelo direito à liberdade dos africanos importados por contrabando, isso dificilmente escapou aos contemporâneos e deixou de ganhar publicidade durante toda a crise, que se arrastou por 1863 e 1864, sendo apenas resolvida depois que o rei Leopoldo da Bélgica arbitrou em favor do Brasil e depois que D. Pedro II recebeu de Edward Thornton, enviado extraordinário e ministro plenipotenciário da coroa britânica, o pedido de reatamento das relações diplomáticas em Uruguaiana, em setembro de 1865.

Essas preocupações "abolicionistas" também tinham servido de justificativa para a defesa da liberdade dos africanos importados por contrabando uma década antes. Em 1850-51, as ações coordenadas do ministro britânico no Brasil, Hudson, e de seu superior, Lorde Palmerston, buscavam incorporar a lei de 1831 no rol da legislação que regulava a abolição do tráfico brasileiro diante do direito internacional e torná-la passivel de aplicação pelo aparato abolicionista britânico. Uma das frentes de batalha foi tentar ampliar a jurisdição britânica sobre todos os africanos importados durante o tráfico ilegal. Até então eram considerados liberated Africans, ou africanos livres, aqueles que haviam sido emancipados pela comissão mista sediada no Rio de Janeiro e entregues ao governo brasileiro para administração da tutela. Em 1850-51, o governo britânico estendeu o status de liberated Africans para africanos ou mesmo crioulos que de várias maneiras vieram para seu domínio, seja fugindo de seus senhores, seja capturados nas atividades de patrulha antitráfico da Royal Navy, sem passar depois pela referida comissão. Palmerston considerava que o direito deles à liberdade se baseava na lei de $1831 .{ }^{15} \mathrm{~A}$ saída de Palmerston do Foreign Office, no final de 1851, graças a desentendimento com a própria Rainha Vitória acerca da condução da política externa na Europa, encerrou a primeira fase "radical" da política britânica em relação aos africanos no Brasil.

A chegada de William Christie, indicado para ministro britânico no Brasil, havia reaberto a questão. Pouco mais de seis meses depois de sua chegada, já em meados de 1860, estava pedindo informações oficiais do governo brasileiro a respeito dos africanos livres transferidos da Fábrica de Ferro de Ipanema para a Colônia de Itapura. ${ }^{16}$ Fez também algumas representações acerca dos africanos ilegalmente escravizados, denunciando a existência de anúncios de africanos nos jornais e a venda deles em leilão sem que as declarações públicas servissem à polícia como prova do 
Christie para Russell, 24/06/1861, transcrito em CHRISTIE, William D. Notes on Brazilian Questions... Op. Cit., p.83-84.

18 lbidem.

TAVARES BASTOS, Aureliano Cândido. Cartas do Solitário: estudos sobre reforma administrativa, ensino religioso, africanos livres, trafico de escravos, liberdade da cabotagem, abertura do Amazonas, communicações com os Estados Unidos, etc. 2a ed. Rio de Janeiro: Typographia da Actualidade, 1863. p.90.

20

Ibidem, p.91.

21

Ibidem, p.107-108. contrabando. ${ }^{17}$ Mas foi da liberdade dos africanos livres que Christie fez sua bandeira mais pública: reclamou da política do governo imperial de utilizar a mão de obra de africanos livres nas instituições públicas sem pagar-Ihes salários, insistiu muito na reclamação de que a maioria deles já havia completado (e ultrapassado) o tempo de tutela e que deveriam ser emancipados, solicitou incansavelmente uma lista dos africanos cuja tutela fora confiada ao governo imperial e talvez tenha também ajudado nas petições de emancipação de africanos livres junto ao Ministério da Justiça. ${ }^{18}$ Vários indícios apontam para uma colaboração entre Francisco Otaviano, Tavares Bastos e Christie na estratégia de dar publicidade ao deplorável tratamento que o governo imperial dispensava à questão dos africanos livres, arrastando indefinidamente os processos de emancipação e resistindo a conceder-Ihes suas cartas de emancipação definitivas.

As Cartas do Solitário, relativas ao tráfico e aos africanos livres, publicadas sob pseudônimo por Tavares Bastos no Correio Mercantil em novembro de 1861, expuseram a questão ao público brasileiro com riqueza de detalhes e referências, o que contribuiu para uma imagem dos africanos livres como vítimas do governo, que Ihes devia, afinal, a emancipação definitiva. Na Carta IX, publicada em 5 de novembro, Bastos elencou os tratados, a legislação de abolição do tráfico e todas as medidas administrativas que regulavam sua administração pelo governo imperial. Nisso, trouxe a público o exemplo das petições dos africanos livres para requerer emancipação: tramitavam por muitas repartições que praticamente inviabilizavam a aplicação do decreto de 24 de dezembro de 1853. Lembrou também aos leitores do conteúdo da lei de 1831, que determinava a reexportação dos africanos livres, e discutiu sua falta de aplicação, segundo ele, motivada por "egoismo e imbecilidade": era conveniente "encher o país de trabalhadores adaptados ao clima".19 0 tráfico ilegal teria, para Bastos, inibido a imigração espontânea. Tavares Bastos ainda sentenciou: "onipotência do poder executivo triunfou: mentiu-se à promessa da reexportação, rasgou-se a lei e sancionou-se um duplo crime contra a honra e contra 0 futuro do pais".20 Sintomaticamente, Bastos abriu com ressalvas a carta seguinte, publicada uma semana depois:

\footnotetext{
Meu caro senhor: presumo haver discutido a questão dos africanos livres dentro dos limites da maior conveniência. Pretendi mostrar a necessidade de conceder-se a carta de alforria a todo aquele que haja concluido o seu tempo de serviço. Foi preciso para isso entrar em considerações acerca do nosso direito escrito; mas, fazendo-o eu creio que não deixei-me arrastar a juizos temerários, a observações perigosas. Então, como agora, todo o meu empenho é colocar a questão em terreno neutro, calmo, pacífico. 0 fim, a que proponho-me, é do maior proveito para o miserável; e quererei, meu amigo, comprometer a sua causa, assustando a propriedade, consternando e provocando os direitos adquiridos? Não apelo para a força, nem excito as paixões: falo ao sentimento e me dirijo à razão. Se eu quisesse compor um poema sombrio, ou escrever um romance incendiário; se quisesse começar uma propaganda tão perigosa quanto inútil, não teria estas reservas nem esta prudência. Desejo ser, não parecer, útil. ${ }^{21}$
}

É muito significativo que Tavares Bastos tenha se preocupado em dar explicações a seu público. É como se tivesse sido acusado de atacar o direito à propriedade sobre os africanos ilegalmente escravizados e precisasse mostrar que não tinha intenções radicais, mas que procurava apenas defender os direitos dos africanos livres. Suas cartas políticas tiveram enorme sucesso naquele momento fértil da política imperial e 
22

LYRA, Heitor. História de Dom Pedro II, 18251891. 3 vols. São Paulo: Companhia Editora Nacional, 1938. p.236; SALLES, Ricardo. As águas do Niágara: 1871: crise da escravidão e o ocaso saquarema. In: GRINBERG, Keila; SALLES, Ricardo (orgs.) Coleção Brasil Imperial, 1871-1889. Rio de Janeiro: Civilização Brasileira, 2009. p.62-64.

23

Análise baseada no levantamento dos volumes IJ6 15 e IJ6 16, Arquivo Nacional - Rio de Janeiro (ANRJ)

24

MAMIGONIAN, Beatriz G. Conflicts over the meanings of freedom: the liberated Africans' struggle for emancipation in Brazil (1840s1860s). In: BRANA-SHUTE, Rosemary; SPARKS, Randy J. (eds.). Paths to freedom: manumission in the Atlantic World. Columbia, SC: University of South Carolina Press, 2009. p.235-254. foram republicadas em dezembro de 1863 , já depois da partida de Christie. É provável que esses escritos seus tenham sido amplificados quando a "questão inglesa" tornou-se a ordem do dia. De qualquer forma, ainda que Tavares Bastos declarasse querer apenas a "alforria" dos africanos livres, a publicidade estava feita e as ideias lançadas para o uso que 0 público quisesse e pudesse fazer. Considerando que a Questão Christie arrastou-se ainda por todo o ano de 1864, pode-se avaliar a disseminação, por meios formais e informais, que tiveram o tema dos africanos, livres e ilegalmente escravizados, e a notícia das estratégias de defesa deles pelos representantes britânicos.

\section{A ebulição política e a formulação da saída gradual}

Naqueles poucos anos, a questão da escravidão havia ficado ainda mais incômoda no Brasil: além da Questão Christie, também a guerra civil norte-americana expôs os riscos da polarização política entre defensores da escravidão e seus críticos, ainda mais ao deixar o Brasil como última nação escravista independente depois da declaração de emancipação de Lincoln, em 1863. Já em janeiro de 1864, D. Pedro II enviou nota a Zacarias de Góis e Vasconcellos aludindo à situação norte-americana e à pressão sofrida da Inglaterra na questão do tráfico, e pedindo que no novo ministério se pensasse "sobre o futuro da escravidão no Brasil". D. Pedro sugeria a emancipação das crianças nascidas das escravas, isto é, apontava para a solução de abolição gradual. ${ }^{22}$ Sintomaticamente, naquele momento se acelerou 0 processo de concessão de cartas de emancipação definitivas aos africanos livres. A análise cronológica dos avisos expedidos pelo ministro da Justiça atesta claramente que já no primeiro semestre de 1864 o número de avisos superou o dos três anos anteriores somados..$^{23} 0$ governo imperial ainda emitiu um novo decreto, em setembro de 1864, reiterando o de dezembro de 1853 e oficializando o direito à emancipação definitiva dos africanos livres que haviam cumprido tutela junto às instituições públicas. 0 Ministério da Justiça buscou nos anos seguintes fechar a "questão dos africanos livres" ao garantir que não houvesse na Corte nem nas províncias quem não tivesse recebido carta de emancipação definitiva e ao realizar uma "matrícula dos africanos livres". Nesse esforço, ficou muito evidente a preocupação do governo com a centralização pelo Ministério da Justiça das decisões sobre emancipação de africanos e o esclarecimento de quem tinha e quem não tinha direito a ser considerado "africano livre". 24

0 clima entre certa camada da sociedade era para radicalismos. Muitos relatos dão conta de como a abolição virou tema discutido nas Faculdades de Direito de São Paulo e de Recife naqueles anos, e de como alguns estudantes abraçaram a causa e a levaram para a política fora das arcadas. Castro Alves publicou em maio de 1863, aos 16 anos, num jornal dos acadêmicos de Direito da Faculdade de Recife, A Canção do Africano, que lhe rendeu fama imediata entre seus pares. Seguiu compondo, declamando publicamente e publicando poemas como 0 Século, que incitava sua geração à ação. Quando chegou a São Paulo, no início de 1868, já era famoso e aclamado por autoridades literárias como Machado de Assis e José de Alencar. Na Faculdade de Direito do Largo São Francisco, para onde se transferiu, encontrou clima francamente abolicionista e crescentemente republicano, e vários professores e colegas muito engajados: José Bonifácio, o moço, Joaquim Nabuco, Afonso Pena, Rodrigues Alves e Rui Barbosa. 
PENA, Eduardo S. Pajens da Casa Imperial: jurisconsultos, escravidão e a Lei de 1871. Campinas: Ed. da Unicamp; Cecult, 2000.

26

PERDIGÃO MALHEIRO, Agostinho Marques. llegitimidade da propriedade constituída sobre o escravo. Revista do Instituto da Ordem dos Advogados Brasileiros, vol.2, n.4, 1863. p.144-145

27

Ibidem.

LARA, Silvia Hunold. Para além do cativeiro: legislação e tradições jurídicas sobre a liberdade no Brasil escravista. In: FONSECA, Ricardo Marcelo; SEELANDER, Airton (orgs.). História do direito em perspectiva: do antigo regime à modernidade. Curitiba: Juruá, 2008. p.325-327 PENA, Eduardo S. Pajens da Casa Imperial...Op. Cit., p.266-267; GRINBERG, Keila. 0 Fiador dos Brasileiros...Op. Cit, p.215-216.

29

PENA, Eduardo S. Pajens da Casa Imperial...Op. Cit., p.290.

30

PERDIGÃO MALHEIRO, Agostinho Marques. Escravidão no Brasil: ensaio histórico-jurídicosocial. 3 Vols. Rio de Janeiro: Typographia Nacional, 1866-1867.
Também se multiplicavam as ações movidas por escravos que chegavam aos tribunais em defesa da liberdade, algumas baseadas em argumentos que provocavam verdadeiros impasses jurídicos. Eduardo Spiller Pena mostrou que essas pressões levaram a debates entre os jurisconsultos do Instituto dos Advogados do Brasil (IAB) a respeito do melhor encaminhamento da questão da escravidão e que, ainda que eles se declarassem em geral contra a escravidão, raramente emitiam julgamento que ferisse 0 princípio da propriedade, que era tido como o pilar da ordem escravista. ${ }^{25}$ Em discurso diante dos colegas do IAB em 1863, intitulado "llegitimidade da Propriedade Constituida sobre o Escravo", Perdigão Malheiro havia contornado habilmente as implicações da lei de 1831, assentado sua crítica à escravidão em razões morais e filosóficas e reafirmado o princípio da liberdade natural, ao sentenciar que

(...) a propriedade do escravo é apenas um direito ou posse dos seus serviços, do seu trabalho. 0 homem nele é reconhecido existir sempre (...). A liberdade natural o escravo a conserva. 0 exercício civil, a capacidade civil somente the é tolhida, mas pela manumissão é-Ihe restituída, como o era já entre os povos da antiguidade. ${ }^{26}$

Reforçando sua sanção à intervenção dos legisladores, completava:

Parece fora de dúvida que a propriedade constituida por ficção sobre o homem a bem de outro homem, não tendo fundamento na lei natural, é toda especial, tolerada pela lei civil por motivos especiais, e por ela regulada; e que a mesma lei pode modificá-la e até extingui-la, obedecendo nisto à lei mais poderosa do Autor da Natureza. ${ }^{27}$

Como saída, Perdigão Malheiro propunha a emancipação gradual baseada na liberdade do ventre, isto é, na libertação das crianças nascidas das escravas. A lei civil que, para Malheiro, apenas tolerava a escravidão também dava elementos para condená-la, porém ele selecionava dela a interpretação conveniente, como fazia com a legislação romana e a legislação colonial. ${ }^{28}$ Como indicou Pena, a estratégia política do discurso de Perdigão Malheiro era a de esvaziar o debate em torno da lei de $1831 .{ }^{29}$ Nos anos seguintes trabalhou em lapidar sua proposta com A Escravidão no Brasil: Ensaio Histórico-Político-Social. Publicado em três volumes, entre 1866 e 1867, buscou pautar a discussão, levar a um público mais amplo um arcabouço de justificativas morais e legais para a escravidão e para a liberdade, e formular embasamento jurídico para a proposta de emancipação gradual baseada na liberdade do ventre. ${ }^{30}$ Ironicamente, em 1871, como deputado, Perdigão votou contra os princípios que defendeu como jurisconsulto.

Em resposta ao avanço do debate e à ameaça da solução radical, ao longo da segunda metade da década de 1860, a discussão a respeito da escravidão ganhou contornos mais claros: cresceu o grupo daqueles que defendiam a intervenção do governo por meio de reformas como a libertação do ventre e a regulamentação do pecúlio e da alforria. Cresceu também o grupo dos radicais que defendiam a aplicação da lei de 1831, enquanto, próximo ao fim da década, se cristalizou uma oposição a qualquer reforma e intervenção do governo na escravidão. Diferiam claramente na interpretação do direito dos senhores à propriedade, em particular dos africanos.

A análise das passagens em que se trata da propriedade é emblemática. Do lado gradualista, D. Pedro II deu o tom quando, na Fala do Trono 
31

Falas do Trono, Desde o ano de 1825 até

1889. Coligidas pela Secretaria da Câmara dos Deputados. São Paulo: Melhoramentos, 1977. p.374.

RODRIGUES, José Honório (ed.). Atas do Conselho de Estado. 13 Vols. Brasília: Senado Federal, 1978, vol.6, p.171-263.

33

Ibidem, vol.7, p.431-466; vol.8, p.3-41.

34

CHACON, Vamireh. Introdução. In: ARAÚJO, José Thomaz Nabuco de. 0 centro liberal. Brasilia: Senado Federal, 1979; ALONSO, Angela. Joaquim Nabuco. São Paulo: Cia das Letras, 2007. de 1867, declarou que, ao encaminhar a questão da emancipação, devia ser "respeitada a propriedade atual" e ao mesmo tempo devia se procurar fazê-la "sem abalo profundo em nossa primeira indústria - a agricultura". ${ }^{31}$ Como ele provavelmente não se referia ao respeito pela propriedade futura gerada do ventre das escravas, é plausivel assumir que novamente sinalizava apoio para uma proposta de saída gradual, esclarecendo de início defender a propriedade constituída sobre os africanos importados por contrabando e seus filhos, para não alarmar os senhores. 0 Imperador encomendou a Pimenta Bueno, então Visconde de S. Vicente, projetos que servissem de base para a discussão. 0 "problema da extinção da escravatura", de forma mais ampla, e os projetos, em específico, foram discutidos no Conselho de Estado pleno em sessões de 2 e 9 de abril de 1867. Eram cinco projetos, sendo o primeiro relativo à emancipação dos filhos das escravas; o segundo propunha a criação de juntas de emancipação, que seriam responsáveis por fiscalizar o processo e por proteger os direitos dos escravos, como de alforria por pecúlio, direito a folga semanal e não separação das famílias; o terceiro criava uma matrícula de todos os escravos do país; 0 quarto emancipava os escravos da nação; e o quinto emancipava os escravos das ordens religiosas. ${ }^{32}$ No ano seguinte, em quatro sessões (16, 23 e 30 de abril e 7 de maio de 1868), foram postos em discussão os artigos já fundidos em um único projeto por Nabuco de Araújo. ${ }^{33}$ Dessas discussões emergiram vários impasses e alguns consensos. Entre os impasses, o problema da propriedade. Os conselheiros mais conservadores se recusavam a aceitar o princípio da liberdade do ventre sem que houvesse indenização dos proprietários pelos escravos que deixariam de ter. Entre os consensos, o mais pertinente a essa discussão era o da necessidade de uma matrícula geral dos escravos.

Em 1868, a queda do gabinete "progressista" de Zacarias de Vasconcelos e o convite do Imperador a Itaboraí para montar um gabinete conservador quando a maioria era liberal desencadearam uma grave crise política, cuja consequência foi incentivar o engajamento ao longo de todo o espectro político. No centro da crise estavam o papel do poder Moderador e o problema da representação política. Liberais exigiam reformas - eleitoral, judiciária, reforma da Guarda Nacional e fim do Senado vitalício, além da emancipação gradual -, mas havia os mais radicais, que, além do aprofundamento das mudanças políticas, davam prioridade à discussão da escravidão e, por vezes, questionavam a propriedade escrava. ${ }^{34} 0$ clima político em 1868 não dava margem à indiferença - o peso do argumento da ilegalidade da escravidão no debate naquele momento ainda resta avaliar de perto. Mas existem alguns indícios de que a questão ganhava publicidade, de várias formas. Os versos de Castro Alves não indicam denúncia explícita da ilegalidade da escravidão. 0 poeta dava vida aos africanos e criava intensa empatia no público com sua humanidade e sofrimento. Por vezes, também os retratava a vingar-se da opressão. Em seu lirismo engajado, Castro Alves criticava a escravidão como desumana e era duro com os que defendiam a abolição apenas gradual. Naqueles anos da segunda metade da década de 1860 , era comum a seu grupo a denúncia da ilegalidade da escravidão por força da lei de 1831 e a defesa da abolição sem muitas demoras. Rui Barbosa, por exemplo, integrava com Luiz Gama e outros o Clube Radical Paulistano, onde discursou, em setembro de 1869, sobre a emancipação dos escravos e, após historiar o processo de emancipação em outros paises, 
não usou meias palavras ao declarar que seria mais fácil alcançá-la no Brasil, pois

35

BARBOSA, Rui. Obras completas de Rui Barbosa. Primeiros Trabalhos. Rio de Janeiro: Ministério da Educação e Saúde, vol.1, tomo I, 1951, p.171-173. 36

CARVALHO, José Murilo. As conferências radicais do Rio de Janeiro: novo espaço de debate In: Nação e cidadania no Império...Op. Cit., p.34.

37

AZEVEDO, Elciene. Orfeu de Carapinha: a trajetória de Luiz Gama na imperial cidade de São Paulo. Campinas: Ed. da Unicamp, 1999.

38

BERTIN, Enidelce. Os meia-cara: africanos livres em São Paulo no Século XIX. Tese (Doutorado em História). Faculdade de Filosofia e Ciências Humanas, Universidade de São Paulo, São Paulo, 2006. p.106 e p.180.

39

AZEVEDO Elciene. Orfeu de Carapinha...Op. Cit., p.111.

40

Ibidem, p.118-119.

COSTA E SILVA, Alberto da. Castro Alves. São

Paulo: Cia das Letras, 2006. p.179.
(...) uma porção imensa da propriedade servil existente entre nós (mais de um terço) além de ilegítima, como toda a escravidão, é também ilegal, em virtude da lei de 7 de novembro de 1831, e do regulamento respectivo (...) donde se conclui que o governo tem obrigação de verificar escrupulosamente os títulos dos senhores, e proceder na forma do decreto sobre a escravatura introduzida por contrabando. ${ }^{35}$

Em contraste, segundo José Murilo de Carvalho, as conferências radicais no Rio de Janeiro nem abordaram a escravidão. ${ }^{36}$ Em São Paulo, o tema extrapolava as conferências políticas e ganhava aplicação prática. Rui Barbosa e Luiz Gama também pertenciam à Loja Maçônica América, entidade que de 1869 em diante adotou formas variadas de lutar contra a escravidão: levantaram-se subscrições para comprar alforrias; elaboraram um plano de emancipação de crianças escravas, principalmente meninas; engajaram as mulheres na campanha; custeavam educação de crianças e adultos pobres; e custeavam a ação de advogados que defendiam escravos na justiça. ${ }^{37}$ Outras lojas maçônicas pelo Brasil afora adotaram algumas medidas em favor da emancipação a partir desse mesmo ano.

A defesa dos africanos tinha várias frentes. Como sabemos, Luiz Gama trabalhava como amanuense da secretaria de polícia onde se processava a emancipação dos africanos livres da província; ele recebeu os africanos livres vindos de diferentes partes da província e entregou suas cartas definitivas de emancipação, registrando-as em livro próprio entre 1865 e $1868 .{ }^{38}$ Fora dali, anunciava sua disposição para defender escravos "em suas causas de liberdade", em muitas ocasiões invocando a lei de 1831, e foi assim que perdeu o emprego e deu publicidade a sua atuação ao levar a questão aos jornais. Elciene Azevedo discute magistralmente a polêmica que se deu quando Gama foi demitido do cargo de amanuense da polícia por ter insultado o juiz municipal suplente "em requerimentos sobre não-verificados direitos dos escravos".39 A publicidade que intencionalmente deu à questão refletiu até no jornal da comunidade britânica no Rio de Janeiro, o Anglo-Brazilian Times, que publicou nota simpática à ação de Gama, considerando-o "the strenuous defender of the rights of persons illegally enslaved by others who had no claim to their services" (o tenaz defensor dos direitos das pessoas ilegalmente escravizadas por aqueles que não têm direito a seus serviços). Mais interessante ainda, porém não surpreendente, é o fato de Tavares Bastos acompanhar a ação de Luiz Gama e de ter guardado a nota do Anglo-Brazilian Times e outra do A Reforma a respeito do mesmo caso. ${ }^{40}$

É difícil minimizar o impacto dessas ações sobre os escravos. Enquanto o público dos poemas abolicionistas e dos discursos radicais talvez não "se dobrasse ao peso das ideias", considerando-as "esdrúxulas, extravagantes", e tivesse, na avaliação ponderada de Alberto da Costa e Silva, dificuldade de se enxergar num país sem escravos, absorvendo só aos poucos o abolicionismo de Castro Alves, aqueles que Luiz Gama levava às barras dos tribunais para enfrentar seus supostos proprietários tinham uma experiência pessoal dos embates políticos em torno do significado da lei de 1831 e podiam multiplicá-la com efeitos mais rápidos na desintegração da ordem escravista. ${ }^{41}$ Do ponto de vista dos senhores, as ameaças à propriedade sobre os africanos importados por contrabando 
42

Lei de $8 / 10 / 1833$. Coleção de Leis do Império de 1833, p. 102-108

43

Decreto 151, de 11/04/1842. Coleção de Leis do Império de 1842, p.227-234. pareciam vir de todos os lados e se tornar mais frequentes à medida que a década de 1860 avançava. Desde a publicação das Cartas do Solitário, em que Tavares Bastos lembrou as consequências funestas da falta de aplicação da lei de 1831 e da crise com a Inglaterra, que demonstrou o alcance diplomático dessas questões, o problema da escravização ilegal dos africanos tinha ganhado o debate público e pautava, veladamente, a discussão sobre a escravidão. Foi em reação à saída radical que os senhores e os parlamentares mais conservadores formularam sua defesa incondicional do direito de propriedade sobre os escravos. Já os reformistas propunham uma solução de compromisso, defendendo a libertação do ventre sem indenização, mas a legalização da propriedade sobre os africanos importados por contrabando. Entre eles, havia consenso em torno da matrícula dos escravos, que finalmente Ihes serviria de prova irrefutável da legalização da propriedade adquirida por contrabando, reconhecidamente instável até então.

\section{Títulos antigos e novos da propriedade sobre os escravos}

Antes da "matrícula especial dos escravos", instituída pela lei de 1871, houve outras matrículas dos escravos, porém parciais e com fins fiscais. A que estava em vigor derivava de uma lei de 1833, regulamentada por um decreto em 1842. A "taxa dos escravos" foi criada pela lei no 59 , de 8 de outubro de 1833, como uma das fontes de renda para custear as 40 mil ações que o governo imperial deteria do Banco do Brasil (em sua segunda encarnação). Seria uma "taxa anual de $2 \$ 000$ paga pelos habitantes das cidades e vilas em razão de cada escravo nelas possuídos, além do número de dois sendo solteiros os proprietários e de quatro sendo casados. Excetuam-se os escravos menores de doze anos e maiores de sessenta".42 Pela lei de orçamento de 31 de outubro de 1835, a taxa foi reduzida para mil réis por escravo de qualquer sexo ou idade residente nas cidades e vilas, mas ainda não foi cobrada. Pelo decreto de 11 de abril de 1842, regulamentou-se a cobrança: seria feita nos órgãos fiscais todo mês de agosto, com base numa "matrícula geral de todos os escravos residentes nas cidades e vilas do império sujeitos à taxa anual".43

0 funcionamento dessa matrícula interessa de perto: 0 alistamento seria feito pela Recebedoria do Município na Corte e nas Mesas de Rendas ou nas Coletorias, em livros próprios e na ordem numérica das casas, incluindo nomes das ruas e bairros (Art. 3), com base em relações assinadas pelos senhores dos escravos (ou aqueles para quem serviam), com declaração de nomes, sexo, cor, idade sabida ou presumida, naturalidade e ofício dos escravos (Art. 5). Muito relevante era a determinação que "no ato da matrícula a ninguém se exigirá o título por que possui o escravo; findo porém o tempo dela nenhum escravo, além dos já matriculados, 0 será de novo sem que o dono apresente o título por que o possui" (Art. 6). Ao fazer vistas grossas para a forma de aquisição da propriedade, o Ministério da Fazenda procurava conseguir a colaboração dos senhores, nem que fosse pela ameaça de aplicação de multas de 10 a 30 mil réis pelo não pagamento (Art. 23). 0 regulamento deixava pouca margem para evasão de divisas, pois registrava que a declaração de matrícula e o comprovante do pagamento da taxa anual seriam documentos obrigatórios para proceder a transações de compra e venda, entrar com causas na Justiça, soltar escravos da prisão, ou obter passaporte na polícia para o caso de sair da cidade (Arts. 21 e 27). Além disso, uma vez matriculados os escravos, os donos 
Por ladinos, entendia-se "todos aqueles que não são havidos por compra feita aos negociantes de negros novos e que entram pela primeira vez no país, transportados da Costa da Africa", Alvará de 03/06/1809, Coleção das Leis do Império, 1809 , p.70.

45

Decreto 2160, de 1/05/1858, Coleção de Leis do Império de 1858, tomo XIX, parte 2, p.244-246, Decreto 2699, de 28/11/1860, Coleção de Leis do Império de 1860, parte 2, p.1097-1101.

46

COSTA, Wilma Peres. Estratégias Ladinas: o imposto sobre o comércio de escravos e a "legalização" do tráfico no Brasil (1831-1850). Novos Estudos CEBRAP, n.67, p.67-74, nov. 2003.

47

Arquivo do Senado (Brasilia), Caixa 30, Maço 2 , pasta 12, Projeto de matrícula dos escravos, 25/04/1834. receberiam "um certificado resumido de cada matrícula dos respectivos escravos, declarando os nomes, sexo, cor e ofício destes e o número da mesma matrícula, e da página do livro onde estiver lançado" (Art. 8).

0 mesmo regulamento de 1842 reformulava a cobrança da meia-siza, imposto criado em 1809 sobre as vendas ocorridas no Estado do Brasil dos escravos ladinos, incluindo aí crioulos e africanos, que era fixado em 5\% do preço das transações, excetuando-se somente as alforrias. ${ }^{44}$ As penas para o não pagamento da siza eram duras: a venda seria anulada, e tanto 0 comprador quanto o vendedor dividiriam o prejuizo pela perda do escravo (Art. 9). Os escrivães responsáveis pela cobrança da meia-siza guardariam registro do pagamento e emitiriam recibos, necessários para a oficialização do registro da transação junto aos tabeliães. A cobrança da taxa anual dos escravos foi novamente regulamentada em 1858 (renovação da matrícula dos escravos) e a da meia-siza em 1860 (fixou em 40 mil réis para cada escravo e estabeleceu obrigatoriedade da escritura pública no caso de venda acima de 200 mil réis). ${ }^{45}$

Ao contrário do que defende Wilma Peres Costa, a matrícula criada para fins fiscais e regulamentada pelo decreto de 11 de abril de 1842 não serviu para legalizar os escravos importados por contrabando, porque ela se destinava aos escravos residentes em cidades e vilas e nunca abrangeu aqueles residentes nas zonas rurais. ${ }^{46}$ Vejamos: se considerarmos o cenário pouco provável em que os esforços arrecadadores do governo imperial tenham tido sucesso, estariam cobertos por registros fiscais os escravos residentes nas cidades e vilas, africanos ou crioulos, e, além deles, os escravos que tivessem sido objeto de transação de compra, venda, permuta, arrematação, cessão, alienação ou renúncia. Escapavam do registro todos aqueles que residissem em zonas rurais e que não tivessem sido objeto de transação, isto é, os africanos que não tivessem trocado de dono desde a chegada ao Brasil e os crioulos que igualmente não tivessem trocado de dono. Considerando ainda que dos crioulos em geral havia registro de batismo, mas dos africanos novos o batismo havia sido irregular, temos que a legislação fiscal, se efetivamente aplicada, pode ter legalizado a propriedade sobre os africanos residentes nas cidades e vilas, mas continuou fazendo vistas grossas para a contínua e crescente escravização dos destinados à zona rural. Isso era conveniente, pois o gabinete do qual o Marquês de Abrantes era ministro da Fazenda não fez gestões para passar a reprimir os desembarques ilegais; pelo contrário. Acrescente-se também que nenhum dos gabinetes posteriores sugeriu estender a taxa dos escravos (e a matrícula) aos escravos rurais.

É importante registrar que até 1834 houve tentativas de aplicar a lei de 1831 . Um projeto de lei de matrícula dos escravos africanos foi apresentado ao Senado em abril de 1834, juntamente com três outros complementares à lei de 1831. A matrícula se justificava pela necessidade de impedir a incorporação de africanos novos e também de dificultar os frequentes roubos de escravos, segundo o preâmbulo. ${ }^{47}$ Pela proposta, os senhores ou administradores dos escravos preparariam róis contendo as informações de cada escravo africano que permitissem identificá-lo e entregariam aos inspetores de quarteirão; estes, por sua vez, aos juízes de paz; e estes, finalmente, à Câmara Municipal de cada localidade, onde as informações seriam registradas nos "livros de matrícula dos escravos africanos". Se não se exigia título de posse no momento do registro (e assim se parecia propor efetivamente legalizar a escravidão daqueles importados 
48

Arquivo do Senado, Caixa 31, Maço 3, pasta 4, Projeto de compra e venda de escravos ladinos, 22/05/1834.

49

Arquivo do Senado, Caixa 31, Maço 3, pasta 4, Projeto de criação de curadorias, 22/05/1834.

50

Para o debate do projeto Barbacena, de uma nova lei de abolição que, no entanto, revogaria a de 1831, ver: Anais do Senado, 1837, 24/07/1837, p.247-248. 0 projeto foi aprovado no Senado, mas enfrentou oposição na Câmara. Ver BETHELL Leslie. A Abolição do Tráfico de Escravos no Brasil. São Paulo: Ed. Expressão e Cultura / EDUSP, 1976. p.70-94). Para representações pela revogação da lei de 1831, Arquivo do Senado Caixa 42, Maço 1, Pasta 24, Representação da Assembleia Provincial de São Paulo, 6/03/1838, e Representação da Assembleia Provincial do Rio de Janeiro, 7/12/1837.

51

CHALHOUB, Sidney. Costumes senhoriais: escravização ilegal e precarização da liberdade no Brasil império. In: AZEVEDO, Elciene; CANO, Jefferson; CUNHA, Maria Clementina; CHALHOUB, Sidney (orgs.). Trabalhadores na cidade: cotidiano e cultura no Rio de Janeiro e em São Paulo, séculos XIX e XX. Campinas: Ed. da Unicamp, 2009. p.23-62.

52

Correspondência do maço IJ6 218 ANRJ citada em CHALHOUB, Sidney. Costumes senhoriais...Op. Cit., p.54.

53

HIGMAN, Barry. Slave Populations of the British Caribbean, 1807-1834. Baltimore: Johns Hopkins U. Press, 1984. p.7-9.

54

Systhema de Medidas Adoptáveis para a Progressiva e Total Extincção do Tráfico e da Escravatura no Brasil. Rio de Janeiro: Typographia do Philantropo, 1852. p.14. até então), a certidão tirada do livro de matrícula seria exigida daí em diante, sob pena de perda do escravo e de punição por redução de pessoa livre à escravidão. Outro projeto, do mês seguinte e apoiado por senadores como o Marquês de Barbacena e Nicolau Vergueiro, propunha que as compras e vendas de escravos ladinos só pudessem ser feitas por escritura pública e que no ato da transação o vendedor declarasse "o título porque [sic] possui o escravo, o tempo, e a pessoa de quem o houve, quando a sua aquisição tiver sido posterior à lei de 7 de Novembro de 1831".48 Estabelecia também processos sumários em que os juizes de paz tinham autoridade de libertar os escravos cujos senhores não apresentassem título de propriedade. Um terceiro projeto criava curadorias nas cidades litorâneas encarregadas de "promover a execução da lei de 7 de novembro de 1831.49 Os três projetos foram discutidos e receberam emendas entre maio e julho de 1834, mas foram rejeitados em conjunto em 5 de outubro do mesmo ano. Nos anos seguintes, sinal da guinada conservadora no Parlamento, haveria muita pressão e tentativas de revogar a lei de $1831 .{ }^{50}$ Dali em diante vigoraria período de instabilidade institucionalizada da liberdade de pessoas livres, tão bem descrito por Sidney Chalhoub, em que se tornou política da chefatura de polícia do Rio considerar escravos os africanos ou crioulos que não tivessem dono declarado e não provassem o contrário..$^{51} \mathrm{~A}$ larga conivência com o tráfico ilegal teria, segundo Chalhoub, provocado esse desrespeito oficioso à presunção de liberdade, que não cessaria com a repressão ao tráfico, no início da década de 1850. Ainda em 1854, em discussão sobre anúncios de leilão de escravos africanos, o chefe de polícia argumentou com Nabuco de Araújo, então ministro da Justiça, que não seria "de modo algum conveniente (...) em nossas atuais circunstâncias" investigar as histórias de africanos jovens anunciados, pois "a mesma suposição pode e deve haver acerca de todos os escravos africanos entre nós existentes". 52

A proposta de uma matrícula dos escravos incluída entre os projetos propostos por Pimenta Bueno ao Conselho de Estado não deixava de ser uma mudança na política de administração do problema da propriedade escrava, que até então operava no "vago extraordinário" dos registros. A matrícula dos escravos havia seguido a proibição do tráfico de escravos no Caribe britânico, primeiro em Trinidad e em St. Lucia, em 1813 e 1814 respectivamente, depois nas outras colônias. ${ }^{53}$ No Brasil, a Sociedade contra o Tráfico de Africanos e Promotora da Colonização, e Civilização dos Indígenas incluiu uma proposta de registro geral dos escravos entre as medidas para a gradual extinção da escravidão formuladas em 1852. 0 registro seguia o fim do tráfico e acompanhava a libertação do ventre, medida central ao projeto.$^{54} 0$ importante é que uma matrícula geral dos escravos com o fim expresso de registro servia para estabelecer oficialmente quem era escravo, e, na falta de registro, quem não era. Não poderiam aparecer novos escravos depois do registro geral, a não ser nos casos previstos em lei. 0 direito de escravizar ficava regulado por lei, e ao mesmo tempo a propriedade escrava estava garantida contra possiveis questionamentos.

Foi justamente assim que o projeto de matrícula foi acolhido no Conselho de Estado e nos debates na Câmara e no Senado, no projeto que se tornou a lei de 28 de setembro de 1871. A se julgar pela historiografia, a "questão do elemento servil" tratava apenas da libertação dos filhos das escravas e da imposição de alforria forçada por pecúlio. Os historiadores 
Isso teria confirmado a profecia do Juiz de Bagé de que muitos casos de pessoas com direito à liberdade permaneciam "sepultados no silêncio." Ver ZUBARÁN, Maria Angélica. "Sepultados no Silêncio": A Lei de 1831 e as ações de liberdade nas fronteiras meridionais do Brasil (1850-1880). Estudos Afro-Asiáticos, ano 29, n.1-2-3, p.281299, 2007.

56

RODRIGUES, José Honório. Atas do Conselho de Estado...Op. Cit., vol. 6, p.250-251.

57

Ibidem, p.197-198; p.236-237.

58

Ibidem, vol. 8, p.28.

59

Ibidem, p.27-32

60

CHALHOUB, Sidney. Machado de Assis: historiador. São Paulo: Cia das Letras, 2003. p.203-227. pouco discutiram o fundo de emancipação ou a matrícula especial. No entanto, a matrícula especial, como procuro argumentar, foi fundamental para estabelecer registro de propriedade sobre os africanos importados por contrabando e seus descendentes e possivelmente também para legalizar a escravidão de muitas pessoas livres "arrebatadas" ou nascidas em propriedades de fronteira em solo estrangeiro e livre. ${ }^{54}$ Pelo projeto de Pimenta Bueno discutido no Conselho de Estado em abril de 1867, a matrícula proposta era a dos "escravos que estavam isentos do imposto denominado taxa dos escravos", que seriam matriculados nas coletorias das paróquias em livros denominados "Registro ou Matrícula Rural dos Escravos". Os registros seriam baseados em informações dos escravos de todas as idades prestadas pelos senhores nas coletorias. As relações deveriam conter declarações de nome, naturalidade, idade, cor, sexo e estado, ofício (se tivessem) e sinais corporais ou outras características que pudessem identificá-los. Os senhores também pagariam 500 réis por escravo, de imposto. As juntas emancipadoras, previstas em outro projeto, seriam responsáveis por fiscalizar a aplicação da matrícula e por promover a liberdade dos escravos que não fossem registrados. ${ }^{55} \mathrm{~A}$ proposta foi acolhida como fundamental, e acessória ao fim almejado, que era o de, libertando as crianças nascidas das escravas, garantir que não houvesse novos escravos no Brasil. 0 Conselheiro Paranhos foi contra a existência de juntas de emancipação, consideradas interferência na autoridade dos senhores, citando o exemplo das colônias britânicas e francesas. Nabuco concordava, opinando que "esse grande aparato é aterrador para os senhores e é para os escravos uma animação funesta". Por outro lado, defendeu medidas mais duras contra aqueles que não registrassem seus escravos. ${ }^{56}$ Encarregado de compilar os projetos e as sugestões feitas, Nabuco de Araújo levou novo projeto à apreciação do Conselho de Estado em abril e em maio do ano seguinte. Por sua proposta, a matrícula ainda seria um complemento àquela feita nas cidades e vilas, incluindo todos os que antes estavam isentos da taxa dos escravos; por ela se cobrariam 300 réis por escravo e se presumiriam livres todos os escravos que não fossem matriculados, "quaisquer que fossem as provas em contrário". Não fazia distinção clara da autoridade encarregada ou do procedimento para a elaboração da matrícula. Um ano depois, em 7 de maio de 1868, a discussão do artigo $7^{\circ}$ do projeto Nabuco novamente no Conselho pleno foi muito reveladora das dificuldades políticas que o projeto como um todo enfrentaria. 0 Marquês de Olinda se posicionou contra a matrícula geral dos escravos, argumentando que a cobrança do imposto seria uma opressão, não pelo valor, mas pela forma de arrecadação: "não teria outro efeito senão muito vexame para as classes mais abastadas". ${ }^{57}$ Outros, como o Visconde de Abaeté, foram contra a presunção de liberdade daqueles que não fossem dados à matrícula, primeiro porque a presunção deveria ser de escravidão e segundo porque não deveria haver sentença contra os senhores em caso em que a culpa não fosse deles. A forma de coação dos senhores para matricular os escravos e os filhos das escravas que nascessem livres também foi motivo de controvérsia. A maioria dos conselheiros concordava, no entanto, com a importância da proposta de matrícula, apesar de discordar a respeito do rigor que deveria acompanhar sua aplicação. ${ }^{58}$ Impasse semelhante se veria na discussão no Parlamento e na aplicação da "matrícula especial", já a cargo do Ministério da Agricultura, como demonstrou Chalhoub. ${ }^{59}$ 
61

Ibidem, p.205-206.

62

Anais da Câmara dos Deputados (ACD), 2/08/1871, p.26.

63

NEEDELL, Jeffrey. The party of order: the Conservatives, the State, and Slavery in the Brazilian Monarchy (1831-1871). Stanford, CA: Stanford University Press, 2006. p.272-314.

64

Parecer e Projeto de lei sobre o Elemento Servil formulado pela Comissão Especial da Câmara designada em maio de 1870. Anais da Câmara dos Deputados, 16/08/1870, p.167

65

Anais do Senado, sessão de 26/09/1871, p.249.
A questão da propriedade foi o grande pomo de discórdia durante todo o debate do projeto na Câmara e no Senado, como muitos autores já indicaram. 0 antagonismo foi se delineando durante as discussões no Conselho de Estado e se acentuou gravemente durante a tramitação do projeto. A divergência residia entre se libertarem sem indenização as crianças nascidas das escravas, ou libertá-las indenizando seus senhores. A opção teria implicações sérias no status civil dessas crianças: no primeiro caso, seriam consideradas livres ou ingênuas; no segundo, libertas, portanto com direitos limitados. A bancada governista, composta de conservadores fiéis a Rio Branco e de liberais reformistas, não admitia indenizar os senhores, apesar de recompensá-los com a tutela sobre as crianças, que implicava explorar seu trabalho até a idade adulta. A bancada de oposição, composta de conservadores dissidentes, se aferrou à ideia da indenização, como se aceitar qualquer interferência na propriedade escrava fosse admitir dúvida sobre sua legitimidade ou legalidade. De fato, os senhores e os parlamentares mais conservadores, incluindo Perdigão Malheiro, rejeitavam o projeto como interferência do governo nas prerrogativas senhoriais, como a concessão de alforria. Muitos autores discutiram essa questão; aqui quero apenas chamar a atenção para a ironia, também apontada por Chalhoub, de os defensores dos senhores de escravos se apegarem com tanta veemência ao argumento da propriedade quando todos sabiam que ela era instável. ${ }^{61}$ Davam provas de admissão quando se referiam, recorrentemente, à "propriedade adquirida de boa-fé" ou a "interesses criados na boa fé abrigados à sombra da lei." ${ }^{2}$ Tudo isso escapou a Needell, para quem o projeto era apenas sobre o ventre livre, e o debate todo se resumiu a protestos dos conservadores por seus direitos constitucionais e contra a interferência inconstitucional do Imperador na política parlamentar. ${ }^{63}$

De fato, a leitura do debate político à luz do problema dos africanos importados por contrabando fornece várias evidências de que essa era uma pendência delicada que estava em renegociação em 1871. Para dar encaminhamento ao projeto, seus defensores precisaram muitas vezes reiterar 0 reconhecimento "dos direitos preexistentes". Assim fez a comissão especial da Câmara designada em maio de 1870, na própria abertura do parecer formulado para defender o projeto de lei. Os deputados associavam suas propostas a uma opção pela previdência e avaliavam que

\footnotetext{
Pretender resolver definitivamente esta transcendente questão sem providenciar sobre a substituição do atual instrumento de produção pelo trabalho livre, sem garantir o direito de propriedade, a riqueza pública e particular e até a tranquilidade e a segurança seria um arrojo tão temerário quão funesto - a precipitação. ${ }^{64}$
}

Também a inércia e a hesitação eram igualadas à precipitação, de modo que qualquer escolha que não fosse a saída gradual era vista como prejudicial aos interesses da nação. Da mesma forma o defendeu Nabuco de Araújo no Senado, dando a entender que as várias forças em jogo forçavam-nos à ação e a admitir alguns prejuízos: "Não quereis as consequências de uma medida reguladora pausadamente, haveis de ter as incertezas da imprevidência. Não quereis os inconvenientes econômicos das Antilhas francesas, podeis ter os horrores de S. Domingos".65 Ao mesmo tempo em que ameaçava, Nabuco buscava afastar os fantasmas da aplicação da lei de 1831, que rondavam os debates públicos radicais, como já vimos. Dizia ele: 
Lei 2040, de 28/09/1871, art. 8. Coleção das Leis do Império. Tomo I, Atos do Poder Legislativo, p.117-151.

69

Ver Decreto 4835, de 1/12/1871, e Regulamento anexo, incluindo os modelos de tabelas. Coleção das Leis do Império. Tomo II, Atos do Poder Executivo, p.708-720. A observação sobre os dados de naturalidade foi feita em SLENES, Robert. 0 que Rui Barbosa não queimou: novas fontes para o estudo da escravidão no século XIX Estudos Econômicos, v.13, n.1, p.123-132, 1983.

70

Ibidem, p.123-132
A emancipação simultânea e imediata está fora de questão. Ela não foi suscitada nem no Senado nem na Câmara dos Deputados onde, a falar a verdade, a discussão se colocou entre o status quo e a proposta do governo (...) A emancipação imediata é um abismo, por causa da transição brusca de dois milhões de homens do estado da escravidão para o de liberdade! Transição fatal em relação aos perigos de ordem pública, fatal em relação à desorganização e aniquilação do trabalho. ${ }^{66}$

E como se selasse um pacto entre os reticentes e o governo, propôs:

Eis aqui, senhores, a necessidade de que a lei seja definitiva. A palavra do governo firme e enérgica deve ser esta: Que descansem os senhores a respeito de seus direitos adquiridos; que confiem os escravos na emancipação gradual. A porfia dos partidos será em aplicar meios eficazes para que esta emancipação gradual seja a mais ampla e a mais leve possivel. ${ }^{67}$

Como Nabuco de Araújo, sabemos, era veementemente contra a indenização dos senhores pelas crianças nascidas das escravas, ele estava mesmo se referindo aos direitos sobre a propriedade dos africanos de contrabando e seus descendentes. E assim foi. A lei de 1871, por meio da matrícula especial de 1872, deu ao governo a autoridade de emitir registros de propriedade sobre todos os que eram mantidos em escravidão ilegal, e sobre seus filhos e netos. Os registros de matrícula seriam documentos obrigatórios, dali em diante, para se fazer transferência de propriedade, registro de penhor ou hipoteca, emitir passaporte dos escravos e lavrar inventários ou partilhas; em suma, seriam indispensáveis para identificar os indivíduos e para certificar que eram escravos.

\section{A matrícula para os senhores e para o Estado}

Alguns receios senhoriais se mostraram fundados. Dos projetos do Conselho de Estado para o que tramitou na Câmara havia desaparecido, talvez por algum acordo na comissão, o quesito "naturalidade" dos escravos. Pelo artigo $8^{\circ}$ da lei aprovada, nas declarações apresentadas pelos senhores constariam nome, sexo, estado, aptidão para o trabalho e filiação. ${ }^{68} 0$ terceiro item do artigo $1^{\circ}$ do "Regulamento para a execução da matrícula especial dos escravos e dos filhos de mulher escrava" sobre as informações que seriam coletadas sobre os escravos já acrescentava cor e profissão. Porém, na elaboração das tabelas, os funcionários do Ministério da Agricultura tomaram alguma liberdade, e no modelo de tabela $B$, onde os senhores listariam seus escravos entre os dados requeridos, estava de volta a naturalidade. Por certo, essa informação ficaria de fora na escrituração desses dados nos livros das coletorias, resultando que o governo não disporia de dados agregados sobre a naturalidade dos escravos, mas que a informação constaria nas declarações de matrícula apresentadas pelos senhores e guardadas nas coletorias. ${ }^{69}$

Segundo Robert Slenes, os senhores de escravos foram mais sinceros nas declarações de matrícula coletadas entre 1872 e 1873 do que nas informações que deram aos recenseadores que passaram em seguida. Segundo ele, os senhores, como um grupo, não atrasaram nem deixaram de registrar seus escravos. Inclusive, aparentemente, tiveram a tendência a diminuir as idades destes, provavelmente se antecipando a uma lei de emancipação dos sexagenários, como havia sido implementada em Cuba. ${ }^{70}$ Disso tudo se tira que os senhores confiaram o suficiente no pacto selado com o governo em 1871 para fornecer os dados de seus escravos para a matrícula. Ao registrarem idades inferiores às reais e, ao mesmo tempo, 
MACEDO SOARES, A. J. Campanha jurídica pela libertação dos escravos (1867-1888). Rio de Janeiro: José Olympio, 1938, p.29-74; SILVA Ricardo Tadeu Caires. 0 resgate da Lei de 7 de novembro de 1831 no contexto do abolicionismo baiano. Estudos Afro-Asiáticos, v.29, n.1-2-3, p.301-340, 2007; AZEVEDO, Elciene. 0 direito dos escravos: lutas jurídicas e abolicionismo em São Paulo. Campinas: Ed. da Unicamp, 2010.

72

Para uma discussão das dificuldades associadas à elaboração do código civil durante o Império, ver GRINBERG, Keila. Código civil e cidadania. 2 ed. Rio de Janeiro: Jorge Zahar, 2002.
Recebido para publicação em dezembro de 2010 Aprovado em fevereiro de 2011 a origem dos africanos, os senhores demonstraram confiança de que a escravização dos africanos não seria questionada, ainda que outra legislação viesse a emancipá-los por outros motivos. Para eles, estaria afastado definitivamente o espectro da lei de 1831.0 governo, de fato, não os traiu, mesmo na década de 1880, quando as ações de liberdade com base na lei de 1831 se multiplicavam nos tribunais e a questão da ilegalidade da escravidão ganhou definitivamente a cena pública. ${ }^{71}$

A leitura do debate político acerca do "encaminhamento da questão servil" na década de 1860 demonstrou que a importação maciça de africanos por contrabando até o início da década de 1850, apesar da conivência do governo com os proprietários, gerou uma instabilidade legal cômoda para os senhores, mas em última instância inconveniente para o Estado nacional. A importação ilegal dos africanos dificultou a implantação de um regime fiscal que incluisse cobrança uniforme de taxas de escravos, atrapalhou a modernização dos levantamentos censitários e, possivelmente, também complicou a redação do código civil. Afinal de contas, que condição atribuir, com justiça, aos africanos importados à revelia da legislação de proibição do tráfico e a seus filhos e netos, todos tidos como escravos "em boa-fé"? ?" Além disso, a escravidão ilegal dos africanos complicou as relações diplomáticas do Brasil com a Inglaterra. Esses e outros casos de instabilidade da propriedade escrava geraram inúmeros incidentes com outros países, como ilustrou a questão com o Uruguai que chegou ao Conselho de Estado em 1863.

0 problema da ilegalidade da propriedade sobre os africanos importados por contrabando pode não ter derrubado os preços dos escravos ou inviabilizado a hipoteca antes da crise da década de 1880, mas se constituiu em tema político com potencial explosivo para a ordem social. Governo e proprietários evitavam, a todo custo, dar publicidade ao direito dos africanos à liberdade com base na lei de 1831, e quando a Questão Christie e a agitação política da década de 1860 o fizeram eles abraçaram a proposta gradualista como solução para evitar a emancipação imediata e dar, mais uma vez, sobrevida à escravidão. Os conservadores mais aguerridos, que rejeitavam qualquer interferência do Estado na questão, foram derrotados em 1871, mas nos anos seguintes reconheceram os méritos da lei.

Sob esse prisma, a matrícula dos escravos criada pela lei de 1871 foi, para além do reconhecimento oficial e legalização da propriedade para os senhores, um passo no fortalecimento da soberania do Estado e na imposição da lei sobre os proprietários de escravos. Pela primeira vez na história do país se teria um levantamento nominal padronizado de toda uma categoria de indivíduos, que tivesse abrangência nacional e que fosse preparado de baixo para cima, isto é, partindo das localidades. Esses registros serviriam para fins de identificação dos indivíduos, apesar de conterem apenas a cor, a idade e o sexo como dados de identificação física. Serviriam também como prova da condição jurídica da pessoa e da propriedade do senhor sobre ela, para o caso de haver dúvida ou necessidade legal. Além disso, seriam a base para a cobrança de taxas que incidiam sobre a posse escrava. Para completar, também permitiriam a implantação de política pública em âmbito nacional, como foi o caso do funcionamento do fundo de emancipação instituído pela lei de 1871, para o qual as juntas classificadoras dependiam da matrícula feita em cada localidade. Em suma, superava-se uma fase de instabilidade legal da propriedade escrava, submetiam-se os proprietários e fortalecia-se o Estado nacional, sempre em nome da manutenção da escravidão e em detrimento da liberdade dos africanos. 